\title{
JASA PRIVATE BANKING PADA LEMBAGA PERBANKAN SEBAGAI SASARAN DAN SARANA PENCUCIAN UANG
}

\author{
Ari Purwadi \\ Fakultas Hukum Universitas Wijaya Kusuma Surabaya \\ e-mail: aripurwadi.fhuwks@yahoo.co.id
}

\begin{abstract}
ABSTRAK
Bank dapat mengalami risiko yang digunakan sebagai sarana dan sasaran oleh pelaku kejahatan untuk mencuci uang hasil kejahatannya. Teknik pencucian uang yang seringkali dilakukan melalui industri perbankan. Hal ini disebabkan bank banyak menawarkan jasa dalam lalu-lintas keuangan yang dapat menyembunyikan atau menyamarkan asal-usul dana. Salah satunya adalah jasa private banking yang ditawarkan oleh bank memberikan keuntungan bagi pelaku kejahatan untuk menyembunyikan hasil kejahatan mereka. Peranan private banker sebagai penasehat bagi para nasabahnya menjadi sangat loyal kepada para nasabah mereka, baik karena alasan profesional maupun karena alasan pribadi. Hal ini mengakibatkan mereka menjadi tidak atau kurang tanggap terhadap tanda-tanda ketidakberesan dari kegiatan para nasabahnya. Budaya kerahasiaan sudah merambah dan merasuk ke dalam industri private banking. Adanya kerahasiaan bank yang cukup ketat, maka berpotensi menjadi sarana dan sasaran pencucian uang.
\end{abstract}

Kata Kunci: private banking, bank, pencucian uang.

\begin{abstract}
Bank can experience the risk used by criminal as purposes to do money laundry for their crime. The technique of money laundry is often used by bank industry. It is occurred because bank offer lots of services in flowing the money which can conceal the history of fund. One of them is private service of bank offered by bank in which it gives advantages for criminal to hide their crime. The role of private banker as advisors must be loyal to their customers, either for professionally or personally. It gives impact to customers that they do not response towards the criminality of the customers'activities. The culture of secret ness has spread and inserted to banking private industry. With the tight bank secret ness, it provides potential for money laundry purposes.
\end{abstract}

Keywords: banking private, bank, money laundry.

\section{PENDAHULUAN}

Masalah pencucian uang saat ini telah berkembang dengan begitu pesat, apalagi jika dikaitkan dengan besarnya dana yang telah ditransaksikan. Menurut beberapa sumber memperkirakan bahwa jumlah dana yang dilakukan pencucian mencapai jutaan hingga milyar US Dollar, yang sebagian besar hasil dari perdagangan gelap, penyelundupan obat-obatan terlarang, penjualan senjata, hasil korupsi, tindak kecurangan serta hasil tindak kejahatan terorganisir lainnya. Praktek pencucian uang dari hasil kejahatan diusahakan untuk diproses melalui kegiatan bisnis normal sehingga akan dapat memasuki (diterima) oleh pasar yang sah, sistem atau aktivitas perekonomian yang wajar.

Perang akan praktek pencucian uang merupakan suatu agenda utama bagi para petinggi dan pembuat kebijakan. Berbagai macam organisasi internasional menempatkan masalah pencucian uang sebagai agenda yang perlu mendapat prioritas utama penanganannya, agenda pembangunan perangkat hukum dan upaya lain dalam pencegahan dan penjatuhan hukuman kepada pelaku pencucian uang terus diupayakan baik secara nasional, regional dan internasional. Pada dekade terakhir ini langkah-langkah pemberantasan praktek pencucian uang mengalami kemajuan yang cukup signifikan, namun demikian pencucian uang merupakan suatu "sasaran yang terus bergerak". Para pelaku mengembangkan teknik-teknik baru, seperti cyber laundering, pengembangan penggunaan jalur pencucian melalui non-lembaga keuangan, memasuki segmen-segmen baru seperti bisnis real estate, bursa saham dan barang-barang seni bernilai tinggi.

Secara formal, upaya pencegahan, pemberantasan pencucian uang di Indonesia dimulai pada tanggal 17 April 2002 yaitu saat diberlakukannya Undang- 
Undang No. 15 Tahun 2002 tentang Tindak Pidana Pencucian Uang. Sesungguhnya, tahapan pencegahan pencucian uang sudah dilakukan sebelum undangundang tersebut lahir, namun lingkupnya hanyalah terbatas pada bank. Hal ini dapat ditunjukkan melalui seperangkat regulasi yang dikeluarkan oleh otoritas perbankan yang lebih dikenal dengan Peraturan Bank Indonesia tentang Prinsip Mengenal Nasabah. Urgensi pengaturan ini, tentu didasari oleh alasan yang kuat terutama mengenai dampak yang ditimbulkan oleh kegiatan pencucian uang dalam perekonomian dan untuk memenuhi prinsip-prinsip pengawasan bank secara efektif sesuai standar internasional.

Dalam bidang ekonomi, pencucian uang dapat merongrong sektor swasta yang sah, karena biasanya pencucian uang dilakukan dengan menggunakan perusahaan-perusahaan (front companies) yang nanti mencampur uang haram dengan uang sah sehingga bisnis yang sah kalah bersaing dengan perusahaanperusahaan tersebut. Disamping itu, pencucian uang merongrong integritas pasar-pasar keuangan, karena lembaga-lembaga keuangan (financial institutions) yang juga mengandalkan dana hasil kejahatan dapat menghadapi adanya bahaya likuiditas. Pencucian uang juga mengakibatkan hilangnya kendali pemerintah terhadap kebijakan ekonominya karena para pencuci uang menanamkan kembali dana-dananya bukan di negara yang dapat memberikan rates of return yang lebih tinggi, tetapi diinvestasikan kembali di negara-negara dimana kegiatan mereka itu kecil kemungkinannya untuk dapat dideteksi. Pencucian uang dapat menimbulkan distorsi dan ketidakstabilan ekonomi karena para pencuci uang tidak tertarik untuk memperoleh keuntungan dari investasi-investasi mereka, tetapi mereka lebih tertarik untuk melindungi hasil kejahatan yang mereka lakukan dan dana yang mereka tempatkan secara ekonomis itu tidak harus bermanfaat bagi negara yang menerima penempatan. Bagi Pemerintah, dampak ikutan selanjutnya adalah meningkatnya kejahatan-kejahatan di bidang keuangan (financial crimes) dan akhirnya menimbulkan biaya sosial yang tinggi (social cost), terutama untuk biaya dalam meningkatkan upaya penegakan hukumnya. Berkaitan dengan adanya potensi akan meningkatnya kejahatan di bidang keuangan tersebut, diperkenalkan prinsip-prinsip pengawasan bank yang efektif oleh Basel Committee on Banking Supervision dalam Core Principles for Effective Banking Supervision, bahwa penerapan akan prinsip mengenal nasabah merupakan faktor yang penting dalam melindungi kesehatan bank dan agar terhindar dari berbagai risiko. Dengan penerapan prinsip tersebut maka bank dapat terhindar dari berbagai risiko yaitu risiko operasional, risiko hukum, risiko terkonsentrasinya transaksi dan risiko menurunnya reputasi karena bank tidak lagi digunakan sebagai sarana dan sasaran oleh pelaku kejahatan untuk mencuci uang hasil kejahatannya (http://www.bis.org/bcbs/ diakses tanggal 25 Juni 2012). Oleh karena itu, dengan penerapan prinsip mengenal nasabah bagi bank, bukan hanya dapat mengendalikan risiko tetapi juga berfungsi dalam upaya pencegahan pencucian uang yang nantinya kejahatan di bidang keuangan akan menurun. Dengan demikian, sebenarnya sasaran utama dalam kegiatan pencegahan dan juga pemberantasan pencucian uang terutama adalah agar angka kriminalitas tindak pidana yang menghasilkan harta kekayaan dapat menurun, aset hasil kejahatan dapat dikejar dan dikembalikan kepada negara atau pihak-pihak yang dirugikan serta untuk memelihara stabilitas sistem keuangan.

\section{PERMASALAHAN}

Berdasarkan uraian di atas, maka dapat dirumuskan permasalahannya sebagai berikut, apa yang dimaksud dengan aktifitas pencucian uang serta tipologinya dan apa modus pencucian uang di Lembaga Keuangan Perbankan melalui Private Bank.

\section{PEMBAHASAN \\ Aktifitas Pencucian Uang dan Tipologinya}

Aktifitas pencucian uang secara umum merupakan suatu cara menyembunyikan atau menyamarkan asal usul harta kekayaan yang diperoleh dari hasil tindak pidana sehingga nampak seolah-olah harta kekayaan dari hasil tindak pidana tersebut sebagai hasil kegiatan yang sah. Lebih rinci di dalam UndangUndang No. 15 tahun 2002 tentang Tindak Pidana Pencucian Uang sebagaimana telah diubah dengan UU No. 25 Tahun 2003 Undang-Undang Tindak Pidana Pencucian Uang (yang selanjutnya disebut UU TPPU), pencucian uang didefinisikan sebagai perbuatan menempatkan, mentransfer, membayarkan, membelanjakan, menghibahkan, menyumbangkan, menitipkan, membawa ke luar negeri, menukarkan, atau perbuatan lainnya atas harta kekayaan yang diketahui atau patut diduga merupakan hasil tindak pidana dengan maksud untuk menyembunyikan atau menyamarkan asal usul harta kekayaan sehingga seolah-olah menjadi harta kekayaan yang sah. UU TPPU telah membatasi bahwa hanya harta kekayaan yang diperoleh dari 24 jenis tindak pidana dan tindak pidana lainnya yang diancam dengan hukuman 4 tahun penjara atau lebih sebagaimana disebutkan dalam Pasal 2 UU TPPU, yang dapat dijerat dengan sanksi pidana 
pencucian uang sebagaimana diatur dalam pasal 3 dan Pasal 6 UU TPPU. Modus kejahatan pencucian uang dari waktu ke waktu semakin kompleks dengan menggunakan teknologi dan rekayasa keuangan. Pencucian uang melibatkan aset (pendapatan atau kekayaan) yang disamarkan sehingga dapat digunakan tanpa terdeteksi bahwa sumbernya adalah kegiatan ilegal. Dengan kegiatan pencucian ini, pendapatan atau kekayaan yang berasal dari kegiatan yang melawan hukum diubah menjadi aset keuangan yang seolaholah berasal dari sumber yang sah atau legal (Yunus Husein, 2007:7).

Secara umum ada tiga tahapan pencucian uang yang dilakukan melalui lembaga-lembaga keuangan khususnya perbankan, usaha real estate, dan penukaran uang (Husein, 2007). Ketiga tahap ini menurut Guy Stessens adalah: placement, layering dan integration (Zulkarnain Sitompul, 2004:9-10).

Placement (penempatan), tahap ini merupakan tahap pengumpulan juga penempatan uang hasil kejahatan di suatu bank atau tempat tertentu yang diperkirakan aman guna mengubah bentuk uang tersebut agar tidak teridentifikasi. Biasanya dana yang ditempatkan berupa uang tunai dalam jumlah besar yang dibagi ke dalam jumlah yang lebih kecil dan ditempatkan di beberapa rekening di beberapa tempat. Dengan demikian tahap penempatan merupakan upaya menempatkan dana yang dihasilkan dari suatu aktifitas kejahatan melaui sistem keuangan. Dalam hal ini terdapat pergerakan fisik uang tunai dari luar sistem keuangan masuk ke dalam sistem keuangan. Kegiatankegiatan ini dapat dilakukan melalui cara-cara sebagai berikut: penempatan dana dalam bentuk tabungan, giro, deposito; pembayaran angsuran kredit; setoran modal secara tunai; penukaran uang; pembelian polis asuransi; pembelian produk sekuritas atau surat-surat berharga (Adrian Sutedi, 2007:23-24).

Dalam kegiatan placement ini, bisa juga dilakukan dengan cara: Layering (pelapisan) diartikan sebagai upaya untuk memisahkan atau lebih menjauhkan hasil kejahatan dari sumbernya atau menciptakan serangkaian transaksi yang cukup kompleks untuk menyamarkan atau mengelabui sumber dana "haram" tersebut, dengan cara-cara sebagai berikut: dana hasil placement, selanjutnya dipindahkan dari suatu rekening atau lokasi tertentu ke rekening atau lokasi lain; pembukaan sebanyak mungkin rekening-rekening perusahaan-perusahaan fiktif untuk menerima dana hasil placement, dengan memanfaatkan ketentuan dari rahasia bank, terutama di negara-negara yang tidak kooperatif dalam upaya memerangi kegiatan pencucian uang; menggabungkan antara uang tunai yang berasal dari kejahatan dengan yang diperoleh dari hasil yang sah; transaksi yang dilakukan dalam jumlah relatif kecil namun dengan frekuensi yang tinggi untuk menghindari pelaporan transaksi tunai (structuring); transaksi dilakukan dengan menggunakan beberapa rekening atas nama individu yang berbeda-beda untuk kepentingan satu orang tertentu (smurfing); melakukan transaksi di bursa saham dengan menggunakan dana dari hasil placement (Adrian Sutedi, 2007:25).

Dengan demikian pelapisan ini merupakan upaya untuk mengurangi jejak asal uang tersebut atau ciriciri asli dari uang hasil kejahatan tersebut atau nama pemilik uang hasil tindak pidana, dengan melibatkan tempat-tempat atau bank di negara-negara dimana kerahasiaan bank itu akan menyulitkan pelacakan jejak uang. Tindakan ini dapat berbentuk transfer dana ke negara lain dalam bentuk mata uang asing, pembelian properti, pembelian saham pada bursa efek menggunakan deposit yang ada di bank A untuk meminjam uang di bank $B$, dan sebagainya.

Integration (penggabungan), yaitu upaya untuk menetapkan suatu landasan sebagai suatu 'legitimate explanation' bagi hasil kejahatan. Disini uang yang telah dicuci melalui placement maupun layering dialihkan ke dalam kegiatan-kegiatan resmi sehingga tampak tidak berhubungan sama sekali dengan aktifitas kejahatan sebelumnya yang mana menjadi sumber dari uang yang dicuci. Pada tahap ini uang yang telah dicuci dimasukkan kembali ke dalam sirkulasi dengan bentuk tertentu sesuai aturan hukum. Dengan demikian, tahap penggabungan ini merupakan tahap mengumpulkan dan menyatukan kembali uang hasil kejahatan yang telah melalui tahap pelapisan dalam suatu proses arus keuangan yang sah. Pada tahap ini uang hasil kejahatan benar-benar telah bersih dan sulit dikenali sebagai hasil tindak pidana, dan muncul kembali sebagai aset atau investasi yang tampaknya legal (Munir Fuady, 2004:169).

Cara-cara yang lazim dilakukan dalam tahapan ini seperti: Menggabungkan uang yang telah dicuci dengan uang yang sah untuk kegiatan bisnis atau investasi yang sah; Melakukan setoran modal bank dengan sumber dana dari perusahaan yang diciptakan untuk menampung hasil uang haram dan sumber dana yang sah; Sumbangan untuk kegiatan sosial melalui yayasan, seperti rumah sakit, pendidikan, amal, dan pendirian tempat ibadah dari uang hasil pencucian; Pemanfaatan lain untuk kegiatan tertentu seperti pembelanjaan untuk konsumtif atau pembiayaan kegiatan lain yang tidak legal.

Ketiga tahapan pencucian uang tersebut pada dasarnya dilakukan untuk menciptakan disassociation 
antara uang atau harta hasil kejahatan dengan si penjahat serta tindak pidananya, sehingga proses hukum konvensional akan mengalami kesulitan dalam melacak si penjahat dan menemukan jenis tindak pidananya. Sebagaimana diketahui, harta kekayaan dari hasil kejahatan merupakan titik terlemah dari kejahatan itu sendiri. Apabila hasil kejahatan dapat ditelusuri, maka dapat secara mudah diidentifikasi para pihak yang terkait (pelaku tindak pidana) dan pada akhirnya teridentifikasi tindak pidananya. Atas dasar hal ini, hadir suatu pendekatan baru dalam mengungkap suatu tindak pidana melalui penelusuran hasil tindak pidana yang dikenal dengan mekanisme anti pencucian uang. Dengan kata lain, pendekatan anti pencucian uang ini, gap antara hasil tindak pidana, perbuatan pidana dan pelaku tindak pidana akan diassociation-kan kembali yang pada akhirnya aparat penegak hukum dengan mudah menjerat si penjahat melalui penelusuran hasil kejahatan itu sendiri.

Proses pendeteksian kegiatan pencucian uang baik pada tahap placement, layering maupun integration akan menjadi dasar untuk merekonstruksi asosiasi antara uang atau harta hasil kejahatan dengan si penjahat. Apabila telah terdeteksi dengan baik, proses hukum dapat segera dimulai, baik dalam rangka mendakwa tindak pidana pencucian uang maupun kejahatan asalnya yang terkait. Inilah yang menjadi alasan utama mengapa PJK diwajibkan melaporkan transaksi keuangan mencurigakan (STR-suspicious transaction report) dan transaksi keuangan tunai (CTR-cash transaction report).

Selain itu, ada empat cara umum atau tipologi yang digunakan dalam pencucian uang sebagai berikut ( $\mathrm{Tb}$. Irman S., 2006:114): Pertama, Tipologi dasar, yaitu: 1. Modus orang ketiga, yaitu dengan menggunakan seseorang untuk menjalankan perbuatan tertentu yang diinginkan oleh pelaku pencurian uang, dengan menggunakan atau mengatasnamakan orang ketiga atau orang lain lagi yang berlainan. Ciri-cirinya orang ketiga adalah: hampir selalu nyata dan bukan hanya nama palsu dalam dokumen, biasanya menyadari bahwa ia dipergunakan, merupakan orang kepercayaan yang bisa dikendalikan, dan hubungannya dengan pelaku sangat dekat sehingga dapat berkomunikasi setiap saat; 2. Modus topeng usaha sederhana, yang merupakan kelanjutan modus orang ketiga, yang kemudian akan diperintahkan untuk mendirikan suatu bidang usaha dengan menggunakan kekayaan yang merupakan hasil tindak pidana; 3 . Modus perbankan sederhana, ini merupakan kelanjutan modus pertama dan kedua, namun juga dapat berdiri sendiri. Disini terjadi perpindahan, sistem transaksi tunai yang berubah dalam bentuk cek kontan, cek perjalanan, atau bentuk lain dalam deposito, tabungan yang dapat ditransfer dengan cepat dan digunakan lagi dalam pembelian aset-aset. Modus ini banyak meninggalkan jejak melalui dokumen rekening koran, cek, dan data lain yang mengarah pada nasabah itu, serta keluar masuknya dari proses transaksi baik yang menuju ke seseorang maupun ke aset-aset, atau ke pembayaranpembayaran lain; 4. Modus kombinasi perbankan atau usaha, yang dilakukan oleh orang ketiga yang menguasai suatu usaha dengan memasukkan uang hasil kejahatan ke bank untuk kemudian ditukar dengan cek yang kemudian digunakan untuk pembelian aset atau pendirian usaha-usaha lain.

Kedua, Tipologi ekonomi, antara lain: 1. Model smurfing, yakni pelaku kejahatan menggunakan sejumlah rekannya untuk memecah sejumlah besar uang tunai dalam beberapa jumlah kecil di bawah batas uang tunai sehingga bank tidak mencurigai kejahatan tersamar tersebut. Kemudian uang tunai ini ditukarkan di bank dengan cek perjalanan atau cek kontan. Bentuk lain adalah dengan memasukkan dalam rekening para smurfing di satu tempat pada suatu bank, kemudian mengambil pada bank yang sama di kota yang berbeda-beda, atau disetorkan ke rekening-rekening pelaku pencucian uang di kota lain sehingga terkumpul dalam beberapa rekening pelaku pencucian uang. Rekening ini tidak langsung atas nama pelaku namun bisa menunjuk pada suatu perusahaan lain atau rekening lain yang identitas pemiliknya disamarkan; 2. Model perusahaan rangka, disebut demikian karena perusahaan ini sebenarnya tidak menjalankan kegiatan usaha apapun, namun dibentuk agar rekening perusahaannya dapat digunakan untuk memindahkan sesuatu atau uang. Perusahaan rangka dapat digunakan untuk penempatan dana sementara sebelum dipindah atau digunakan lagi. Perusahaan rangka dapat terhubung antara satu dengan yang lain. Misalnya, saham 'PT A' dimiliki oleh 'PT B' yang berada di daerah atau negara lain, sementara saham 'PT B' sebagian dimiliki oleh 'PT A, PT B, PT C' dan/atau 'PT D' yang berada di daerah atau negara lain; 3. Modus pinjaman kembali, yaitu suatu variasi dari kombinasi modus perbankan dan modus usaha. Contohnya, pelaku pencucian uang menyerahkan uang hasil tindak pidana kepada A (orang ketiga), dan A memasukkan sebagian dana tersebut ke bank B dan sebagian dana juga didepositokan ke bank C. Selain itu A meminjam uang ke bank D. Dengan bunga deposito bank C, A kemudian membayar bunga dan pokok pinjamannya dari bank D. Dari segi jumlah memang terdapat kerugian karena harus membayar bunga 
pinjaman, namun uang ilegal tersebut telah berubah menjadi uang pinjaman yang bersih dengan dokumen yang lengkap; 4. Modus under invoicing, adalah modus untuk memasukkan uang hasil tindak pidana dalam pembelian suatu barang yang nilai jualnya sebenarnya lebih besar daripada yang dicantumkan dalam faktur; 5. Modus over invoicing, merupakan kebalikan dari modus under invoicing. Modus over invoicing, sebenarnya tidak melibatkan barang yang diperjualbelikan, tetapi menggunakan faktur yang dijadikan bukti pembelian (penjualan fiktif) sebab penjual dan pembeli sebenarnya adalah pelaku dari pencucian uang; 6 . Modus pembelian kembali, yaitu pelaku pencucian uang menggunakan dana yang telah dicuci untuk membeli sesuatu yang telah ia miliki.

Ketiga, Tipologi IT (Information Technology), yaitu: 1. Modus e-Bisnis, modusnya menyerupai Multi Level Marketing (MLM), namun menggunakan sarana internet; 2. Modus scanner merupakan tindak pidana pencucian uang dengan pidana asal berupa penipuan dan pemalsuan atas dokumen-dokumen transaksi keuangan.

Keempat, Tipologi high technology, merupakan suatu bentuk kejahatan yang skemanya terorganisir namun orang-orang kunci yang terlibat tidak saling mengenal, nilai uang relatif tidak besar tetapi bila dikumpulkan menimbulkan kerugian yang sangat besar. Cara ini dikenal dengan nama modus cleaning karena kejahatan ini biasanya dilakukan dengan menembus sistem database suatu bank.

Dalam perkembangannya, tindak pidana pencucian uang menjadi semakin kompleks, melintasi batasbatas yurisdiksi, dan menggunakan modus yang semakin variatif, memanfaatkan lembaga di luar sistem keuangan, bahkan telah merambah ke berbagai sektor. Untuk mengantisipasi hal itu, Financial Action Task Force (FATF) on Money Laundering kini telah mengeluarkan standar internasional yang menjadi ukuran bagi setiap negara dalam pencegahan dan pemberantasan tindak pidana pencucian uang dan tindak pidana pendanaan terorisme yang dikenal dengan Revised 40 Recommendations dan 9 Special Recommendations (Revised 40+9) FATF, antara lain mengenai perluasan Pihak Pelapor (reporting parties) yang mencakup pedagang permata dan perhiasan atau logam mulia dan juga pedagang kendaraan bermotor (Undang-Undang No. 8 Tahun 2010).

Dalam rangka mencegah dan memberantas tindak pidana pencucian uang perlu dilakukan kerjasama regional dan internasional melalui forum bilateral atau multilateral agar intensitas tindak pidana yang menghasilkan atau melibatkan harta kekayaan yang jumlahnya besar dapat diminimalisasi (UU TPPU No. 8 Tahun 2010).

Penanganan tindak pidana Pencucian Uang di Indonesia yang dimulai sejak disahkannya UndangUndang No. 15 Tahun 2002 tentang Tindak Pidana Pencucian Uang sebagaimana yang telah diubah dengan berlakunya Undang-Undang No. 25 Tahun 2003 tentang Perubahan atas Undang-Undang No. 15 Tahun 2002 tentang Tindak Pidana Pencucian Uang, telah menunjukkan arah yang positif. Hal itu, tercermin dari meningkatnya kesadaran dari pelaksana Undang-Undang tentang Tindak Pidana Pencucian Uang, seperti penyedia jasa keuangan dalam hal melaksanakan kewajiban pelaporan, juga Lembaga Pengawas dan Pengatur dalam pembuatan peraturan, Pusat Pelaporan dan Analisis Transaksi Keuangan (yang selanjutnya disebut PPATK) dalam kegiatan analisis, dan penegak hukum dalam menindaklanjuti hasil analisis hingga penjatuhan sanksi pidana dan/atau sanksi administratif (UU TPPU No. 8 Tahun 2010).

Upaya yang dilakukan tersebut dirasakan belum optimal, antara lain karena peraturan perundangundangan yang ada ternyata masih memberikan ruang timbulnya penafsiran yang berbeda-beda, adanya celah hukum, kurang tepatnya pemberian sanksi, belum dimanfaatkannya pergeseran beban pembuktian, keterbatasan akses informasi, sempitnya cakupan pelapor dan jenis laporannya, serta kurang jelasnya tugas dan kewenangan dari para pelaksana UndangUndang ini (UU TPPU No. 8 Tahun 2010).

Dalam rangka memenuhi kepentingan nasional dan menyesuaikan standar internasional, maka dari itu perlu disusun Undang-Undang tentang Pencegahan dan Pemberantasan Tindak Pidana Pencucian Uang sebagai pengganti Undang-Undang No. 15 Tahun 2002 tentang Tindak Pidana Pencucian Uang sebagaimana telah diubah dengan Undang-Undang No. 25 Tahun 2003 tentang Perubahan atas Undang-Undang No. 15 Tahun 2002 tentang Tindak Pidana Pencucian Uang (UU TPPU No. 8 Tahun 2010).

Materi muatan yang terdapat dalam UU TPPU No. 8 Tahun 2010, antara lain: 1. redefinisi pengertian hal yang terkait dengan tindak pidana pencucian uang; 2 . penyempurnaan kriminalisasi tindak pidana pencucian uang; 3 . pengaturan tentang penjatuhan sanksi pidana dan sanksi administratif; 4. pengukuhan penerapan prinsip mengenali pengguna jasa; 5 . perluasan pihak pelapor; 6 . penetapan mengenai jenis pelaporan oleh penyedia barang dan/atau jasa lainnya; 7. penataan mengenai Pengawasan Kepatuhan; 8. pemberian kewenangan kepada pihak pelapor untuk menunda transaksi; 9. perluasan kewenangan Direktorat Jenderal 


\section{P ERSPEKTIF \\ Volume XVII No. 1 Tahun 2012 Edisi Januari}

Bea dan Cukai terhadap pembawaan uang tunai dan instrumen pembayaran lain ke dalam atau ke luar daerah pabean; 10. pemberian kewenangan kepada penyidik tindak pidana asal untuk menyidik dugaan tindak pidana pencucian uang; 11 . perluasan instansi yang berhak menerima hasil analisis atau pemeriksaan PPATK; 12 . penataan kembali kelembagaan PPATK; 13. penambahan kewenangan pada PPATK, termasuk juga kewenangan untuk menghentikan sementara transaksi; 14. penataan kembali akan hukum acara pemeriksaan tindak pidana pencucian uang; dan 15. pengaturan mengenai penyitaan Harta Kekayaan yang berasal dari tindak pidana.

Pengertian pencucian uang yang diatur dalam UU TPPU No. 25 Tahun 2003 adalah perbuatan dengan menempatkan, mentransfer, membayarkan, membelanjakan, menghibahkan, menyumbangkan, menitipkan, membawa ke luar negeri, menukarkan, atau perbuatan lainnya atas harta kekayaan yang diketahui atau patut diduga merupakan hasil tindak pidana dengan maksud untuk menyembunyikan, atau menyamarkan asal usul harta kekayaan sehingga seolah-olah menjadi harta kekayaan yang sah (Pasal 1 angka 1 Undang-Undang No. 25 tahun 2003 tentang Perubahan atas Undang-Undang No. 15 tahun 2002 tentang Tindak Pidana Pencucian Uang).

Sedangkan dalam UU TPPU No. 8 Tahun 2010, pengertian pencucian uang mengalami perluasan, menjadi segala perbuatan yang memenuhi unsurunsur tindak pidana sesuai dengan ketentuan dalam Undang-Undang ini (Pasal 1 ayat 1 UU TPPU No. 8 Tahun 2010).

\section{Pencucian Uang di Lembaga Keuangan Perbankan melalui Private Bank}

Sering kita mendengar istilah "Money Laundering" atau jika dialihbahasakan menjadi Bahasa Indonesia menjadi "pencucian uang", mungkin secara mudah kita akan dapat menebak apa yang dimaksud dengan tindakan pencucian uang tersebut. Tetapi untuk lebih memperjelasnya terdapat beberapa definisi mengenai Money Laundering yang dapat dijadikan acuan. The Financial Action Task Force on Money Laundering (FATF) mendefinisikan "Money Laundering is the processing of these criminal proceeds to disguiese their ilegal origin" sedangkan RAND merupakan organisasi nonprofit (lembaga think thank) yang didirikan sejak tahun 1946 berkantor pusat di Amerika yang berkecimpung dalam bidang penelitian dan pengembangan mendefinisikan "Money Laundering is an ilegal activity through which proceeds take on outward appereance of legitimacy".
Secara umum dari kedua definisi tersebut dapat diterjemahkan bahwa money laundering merupakan "proses menyamarkan atas hasil atau keuntungan yang diperoleh dari tindak kejahatan sehingga kelihatan seolah-olah diperoleh dengan cara yang legal (sesuai dengan aturan yang berlaku).

Kegiatan pencucian uang merupakan konsekuensi yang hampir pasti terjadi pada semua perolehan keuntungan yang berpotensi membangkitkan unsurunsur kejahatan. Pada umumnya pelaku cenderung untuk mencari daerah yang memiliki risiko rendah atau lemah atau tidak efektif dalam mendeteksi kegiatan pencucian uang. Karena tujuan pencucian uang adalah untuk mendapatkan dana tersebut kembali kepada orang-orang yang megeneratenya, pelaku umumnya lebih memilih untuk memindahkan dananya ke daerahdaerah yang financial system-nya telah established. Perbedaan antara sistem anti money laundering di suatu negara akan dapat dieksploitasi oleh pelaku, yang cenderung untuk memindahkan jaringan mereka ke negara-negara dan sistem keuangan yang lemah atau yang memiliki tindakan pencegahan yang tidak efektif (ineffective countermeasures).

Teknik pencucian uang yang seringkali dilakukan adalah melalui industri perbankan. Hal ini disebabkan karena bank banyak menawarkan jasa dalam lalu lintas keuangan yang dapat menyembunyikan atau menyamarkan asal usul dana (NHT Siahaan, 2005: 16). Salah satunya adalah jasa private banking yang ditawarkan oleh bank itu memberikan keuntungan bagi pelaku kejahatan untuk menyembunyikan hasil kejahatan mereka.

Private banking adalah jasa layanan perbankan yang ditawarkan oleh suatu private bank. Private bank adalah bank atau unit operasional di dalam suatu bank yang mengkhususkan diri untuk memberikan jasa-jasa keuangan kepada orang-orang jasa (pribadipribadi yang kaya). Pada umumnya, private bank memberikan jasa-jasa keuangan kepada orang-orang kaya, dengan bertindak sebagai penasihat keuangan (financial advisor), estate planner, credit source dalam hal mengupayakan kebutuhan kredit kepada nasabahnya, dan juga manajer investasi (investment manager) yang mana bertugas menginvestasikan dan mengelola investasi nasabah (NHT Siahaan, 2005:16). Untuk dapat membuka suatu rekening (account) pada suatu private bank, calon nasabah biasanya harus mampu menempatkan uang dalam jumlah besar, dan sebagai timbal balik dari penempatan uangnya yang berjumlah besar itu, maka private bank yang bersangkutan menugaskan pegawainya yang disebut private banker atau relationship manager 
untuk bertindak sebagai penghubung antara nasabah dan bank, dan memfasilitasi penggunaan jasa-jasa keuangan yang banyak ragamnya oleh nasabah yang bersangkutan. Dengan kata lain, private bank berupaya untuk menyediakan global wealth management untuk orang kaya yang menjadi nasabahnya.

Bukti-bukti telah menunjukkan bahwa private bank sangat rentan terhadap praktik-praktik pencucian uang. Tuduhan seorang banker dari American Express di tahun 1994 merupakan peringatan dini terhadap hal tersebut. Di tahun 1995, skandal Raul Sallinas, saudara mantan Presiden Meksico, Carlos Sallinas, merupakan kejadian kedua yang menghebohkan. Di tahun 1998, operasi pencucian uang Casablanca, mengakibatkan dihukumnya beberapa private banker di Meksiko (Sutan Remy Sjahdeini, 2004:332).

Keadaan ini membuat para regulator perbankan menunjukkan keprihatinannya yang makin meningkat terhadap praktik-praktik pencucian uang di beberapa private bank. Di tahun 1996, Federal Reserve Bank of New York, telah melakukan penelitian terhadap kegiatan-kegiatan private banking dari 40 lembaga keuangan Amerika Serikat dan asing yang melakukan kegiatannya di wilayah New York. Dari hasil penelitian tersebut, terungkap beberapa faktor keterkaitan dengan pelayanan private banking yang dapat meningkatkan kerentanan private banking terhadap faktor tersebut (Sutan Remy Sjahdeini, 2004:332) adalah:

Pertama, peranan private banker sebagai penasehat bagi para nasabahnya. Private banker memainkan peranan kunci dalam sistem private banking. Mereka dilatih untuk dapat melayani kebutuhan-kebutuhan nasabahnya dengan baik, untuk mengatur pembukaan rekening-rekening bagi keperluan para nasabah itu, mengatur dan melaksanakan pemindahan uang para nasabah ke seluruh dunia dengan cara menggunakan sistem keuangan yang rumit dan dengan menggunakan sarana-sarana kerahasiaan. Private bank mendorong para private banker dari bank tersebut agar mau membangun hubungan pribadi dengan para nasabah mereka, mengunjungi rumah-rumah pribadi para nasabah tersebut, dan juga mengurus urusan-urusan keuangan para nasabah itu. Akibatnya, private banker tersebut menjadi sangat loyal kepada para nasabah mereka, baik karena alasan profesional maupun karena alasan pribadi. Hal ini mengakibatkan mereka menjadi tidak atau kurang tanggap terhadap adanya tanda-tanda ketidakberesan dari kegiatan para nasabahnya. Selain itu, private banker dapat menggunakan keahliannya mereka sehubungan dengan sistem yang berlaku di banknya untuk dapat menghindarkan birokrasi bank menghalangi pemberian pelayanan kepada kebutuhan- kebutuhan para nasabah mereka, sehingga lebih jauh dapat menghindarkan sistem pengawasan yang dirancang untuk dapat mendeteksi atau mencegah praktek-praktek pencucian yang dilakukan oleh para nasabah.

Kedua, budaya adanya kerahasiaan dalam melayani nasabah. Budaya kerahasiaan sudah merambah dan merasuk ke dalam industri private banking. Salah satu contoh adalah pembukaan rekening-rekening tanpa nama yang hanya memakai nomor, sebagaimana hal itu dilakukan oleh bank-bank di Swiss. Ada beberapa lapis kerahasiaan lain yang digunakan oleh private banking dan para nasabahnya untuk tujuan menyamarkan rekening-rekening dan transaksi-transaksi nasabah. Misalnya private bank sering mendirikan perusahaanperusahaan gadungan dan trust untuk kepentingan nasabahnya dengan maksud untuk menyembunyikan identitas dari pemilik sebenarnya dari suatu rekening bank. Private bank juga membuka berbagai rekening dengan memakai nama yang disamarkan. Misalnya saja dalam kasus Raul Sallinas, private bank dari Citibank menciptakan suatu trust dengan memakai kode nomor dan perusahaan gadungan yang disebut Trocca Ltd. Perusahaan tersebut bertindak sebagai pemilik rekening bagi kepentingan Sallinas juga keluarganya. Private bank yang bersangkutan itu menyembunyikan kepemilikan Sallinas atas Trocca Ltd. dengan menghilangkan namanya dari dokumendokumen pendirian Trocca Ltd. dan menggunakan perusahaan-perusahaan gadungan lainnya sebagai para pemegang saham, para direktur, dan para pejabat dari Trocca Ltd. Di dalam komunikasi intern bank tersebut, secara konsisten, Citibank tidak menyebut nama Sallinas, tetapi hanya menggunakan kode nama, yaitu Confidential Client Number 2 atau CC-2. Sementara itu pula, kantor pusat private bank dari Citibank yang berkedudukan di Swiss (pada waktu itu kantor pusat unit private bank dari Citibank bukan berkedudukan di New York tetapi di Swiss), membuka rekening khusus untuk Sallinas dengan nama samaran Bonaparte. Halhal tersebut di atas itu merupakan beberapa hal yang dilakukan oleh Citibank untuk memenuhi permintaan Sallinas agar Citibank mengurus rekening-rekeningnya dengan menerapkan kerahasiaan yang sangat ketat. Di samping mendirikan perusahaan-perusahaan gadungan dengan menggunakan kode-kode, sejumlah private bank juga menjalankan kegiatan usahanya di yurisdiksi (negara) yang menerapkan ketentuan kerahasiaan yang sangat ketat, misalnya Swiss dan Caynan Island, yang memberikan sanksi pidana terhadap pengungkapan informasi oleh bank berkaitan dengan nasabah mereka. Undang-Undang Kerahasiaan tersebut begitu ketatnya, 
sehingga menghalangi pula dapat dilaksanakannya pengawasan internal oleh bank tersebut. Misalnya, apabila seorang pegawai menemukan masalah di salah satu kantornya yang terletak di yurisdiksi (negara) yang menganut ketentuan-ketentuan kerahasiaan yang sangat ketat, pegawai tersebut dilarang oleh undangundang yang berlaku di wilayah setempat untuk memberi informasi tertentu mengenai nasabah yang bersangkutan kepada pegawai-pegawai sejawatnya di Amerika Serikat, sekalipun mereka adalah bagian dari operasi bank yang sama.

Bagi para auditor bank dan para pejabat kepatuhan bank tersebut berlaku pula larangan-larangan yang sama. Setiap laporan audit atau laporan kepatuhan yang dikirimkan ke luar yurisdiksi (negara) tersebut harus terlebih dahulu dibersihkan dari informasi yang menyangkut nasabah. Apabila pegawai bank dari kantornya di Amerika Serikat menghendaki informasi tambahan mengenai suatu masalah yang menyangkut nasabah-nasabah tertentu dari yurisdiksi (negara) tersebut, maka pegawai tersebut harus pergi ke yurisdiksi (negara) tersebut untuk mendiskusikan masalahnya secara terperinci atau untuk memeriksa sendiri dokumentasi yang terkait. Bahkan apabila pegawai dari Amerika Serikat tersebut datang ke yurisdiksi (negara) tersebut, ketentuan akan larangan tersebut tetap juga akan berlaku untuknya.

Sebelum memperkenankan seorang pegawainya pergi ke Swiss, private bank seperti J.P. Morgan dan Citibank mengharuskan para pegawai yang ditugaskan oleh mereka itu untuk lebih dahulu menandatangani suatu surat pernyataan larangan mengungkapkan temuannya, dan mengingatkan mereka bahwa hukum Swiss melarang ungkapannya informasi mengenai nasabah yang mana diperoleh oleh mereka di Swiss kepada siapa pun juga sekalipun kepada pejabatpejabat lain di bank tersebut di kantornya di Amerika Serikat. Seandainya suatu private bank di Amerika Serikat memberitahukan kepada kantornya di Swiss bahwa seorang nasabah dicurigai telah melakukan pencucian uang dan diminta agar rekening-rekening yang berkaitan dengan orang itu ditutup, hukum Swiss melarang kantor bank itu di Swiss, untuk mengungkapkan adanya rekening-rekening tersebut (sekalipun rekening-rekening itu nyata memang ada). Apabila pejabat bank Amerika Serikat itu meminta agar diberikan konfirmasi tentang penutupan rekeningrekening tersebut, maka pejabat bank tersebut harus terbang ke Swiss untuk memperoleh konfirmasi tersebut. Sekembalinya dari Swiss, pejabat private bank tersebut tidak dapat, tanpa melanggar hukum Swiss, untuk menyampaikan informasi mengenai rekening tertentu pada atasannya di Amerika Serikat. Intinya adalah bahwa pegawai-pegawai suatu private bank tidak dapat melakukan diskusi terbuka, sekalipun di luar Swiss, mengenai apa yang dilakukan oleh banknya di Swiss tanpa melanggar hukum Swiss. Ketidakbiasaan itu adalah karena mereka terikat dengan isi pernyataan larangan mengungkapkan temuannya yang mana telah ditandatangani sebelum mereka pergi ke Swiss untuk memperoleh informasi tersebut.

Ketiga, longgarnya ketentuan akan pengawasan pencucian uang. Disamping budaya kerahasiaan dalam melayani nasabah, private bank melakukan kegiatannya dalam iklim budaya ketidakpedulian atau keengganan untuk melakukan pengawasan terhadap praktik-praktik tindakan pencucian uang, misalnya untuk menerapkan due diligence requirement dan account monitoring. Masalah fundamental bagi para private banker adalah keharusan untuk melakukan secara serentak berbagai peranan, yaitu di satu pihak harus membangun hubungan pribadi dengan nasabah dan mengusahakan agar dana simpanan nasabah makin meningkat, tetapi di pihak lain harus pula memantau rekening-rekening mereka berkenaan dengan kegiatan yang mencurigakan dan harus menanyakan kepada nasabah mengenai transaksi-transaksi tertentu yang dilakukan oleh nasabah. Sifat manusia membuat kedua yang saling bertentangan ini sulit dilaksanakan sehinggga berakibat kewajiban mencegah pencucian uang menjadi terbengkalai.

Keempat, tingkat persaingan yang tinggi dalam industri private banking. Karena tingginya tingkat keuntungan yang diperoleh oleh bank dari bisnis private banking, maka bank-bank saling bersaing secara ketat untuk merebut nasabah. Tekanan yang datangnya dari persaingan dan dari kebutuhan untuk ekspansi merupakan disinsentif bagi para private bank untuk menerapkan pengawasan anti-pencucian uang yang ketat karena dikuatirkan dapat menggangu masuknya bisnis baru atau menyebabkan nasabahnasabah yang telah ada pindah ke bank lain.

Kelima, jenis-jenis produk dan adanya jasa private banking memberikan kesempatan pencucian uang. Produk-produk dan jasa-jasa yang ditawarkan oleh suatu private bank dapat memberikan kesempatan bagi para pencuci uang untuk melakukan pencucian uang. Produk-produk dan jasa-jasa yang dimaksud adalah (Sutan Remy Sjahdeini, 2004:338-343):

Pertama, Multiple Accounts. Nasabah-nasabah private bank sering, dan menginginkan, memiliki banyak rekening bank dan banyak lokasi. Ada yang berupa personal checking account, money market 
account, atau credit card account. Rekening-rekening tersebut ada yang atas nama satu atau lebih perusahaanperusahaan gadungan. Multiple Investment Account adalah yang biasanya dimiliki pula oleh para nasabah private bank, termasuk mutual funds, stocks, bonds, dan time deposits. Sementara itu tidak satu private bank pun yang memiliki data base yang mana secara otomatis dapat mengkompilasi semua informasi yang berkaitan dengan seorang nasabah tertentu. Beberapa bank sedang dalam proses memasang sistem yang memungkinkan dapat melakukan sentralisasi informasi mengenai nasabah dan mengidentifikasi rekeningrekening terkait yang menggunakan nama-nama yang berbeda. Namun sistem tersebut bagaimanapun juga sangat tergantung kepada kesediaan dan kerajinan private banker yang bersangkutan untuk mengupdate informasi tersebut.

Kedua, Secrecy product. Kebanyakan private bank menawarkan sejumlah produk dan jasa yang memberikan kerahasiaan mengenai kepemilikan dana atas nasabah yang bersangkutan. Diantaranya, adalah offshore trust, shell corporations, special name accounts, dan kode yang digunakan untuk menunjuk kepada nasabah yang bersangkutan dan menunjuk kepada transfer dana. Adalah hal yang sudah biasa bagi suatu private bank untuk menggunakan perusahaan-perusahaan gadungan bagi kepentingan para nasabahnya. Perusahaan gadungan tersebut sering disebut dengan Private Investment Corporation (yang selanjutnya disebut PIC). Perusahaan-perusahaan itu biasanya didirikan di yurisdiksi (negara) seperti Cayman Islands atau Channel Islands, yaitu negaranegara yang menerapkan larangan bagi bank untuk dapat mengungkapkan beneficial owner dari PIC tersebut. Private bank yang bersangkutan kemudian membuka rekening bank dengan nama PIC tersebut, yang kemudian memungkinkan pemilik PIC untuk menyembunyikan identifikasinya sebagai pemegang rekening tersebut.

Ketiga, Moment of Funds. Rekening-rekening transaksi nasabah private bank seringkali melibatkan dana yang sangat besar jumlahnya. Besarnya transaksitransaksi nasabah yang demikian itu meningkatkan kerentanan bank terhadap pencucian uang, karena dengan demikian bank akan menjadi tempat menarik bagi pencuci uang yang membutuhkan pemindahan dana-dana besar tanpa harus menarik perhatian. Di samping itu, kebanyakan private bank memberikan produk-produk dan jasa-jasa yang dapat memfasilitasi dengan cepat dan dengan rahasia serta sulit dilacak pemindahan dana melalui lintas batas beberapa negara. Sebagai contoh, private bank secara rutin memfasilitasi wire transfers yang jumlahnya besar ke dalam atau ke luar antara rekening nasabah tertentu di berbagai negara. Beberapa private bank memindahkan dana untuk nasabah-nasabah mereka melalui concentration accounts atau suspense accounts, yaitu rekeningrekening yang dibuka oleh private bank untuk tujuan administrasi guna menyimpan dana yang diterima dari berbagai penjuru sebelum akhirnya dana-dana itu didepositokan di rekening-rekening yang sebenarnya. Dana-dana nasabah yang ditempatkan di suatu private bank dapat melewati suatu concentration accounts dalam perjalanannya untuk akhirnya ditempatkan di rekening milik nasabah. Masalah yang timbul apabila suatu private bank membolehkan nasabah-nasabah mereka memindahkan dana melalui concentration accounts dan kemudian langsung dikirim ke rekening lain tanpa terlebih dahulu melewati rekening milik nasabah. Apabila terjadi hal seperti itu, maka danadana tersebut tidak tercatat terasosiasi dengan nasabah tertentu dari bank tersebut.

Keempat, Credit. Jasa lain yang biasa diberikan oleh suatu private bank adalah pemberian kredit kepada para nasabahnya dengan jaminan berupa uang simpanan nasabah pada bank tersebut. Praktik seperti ini memungkinkan bank untuk memperoleh bukan saja fee dari jasa bank itu mengelola simpanan-simpanan nasabah, tetapi juga memperoleh bunga dari pinjaman yang diberikan oleh nasabah tersebut. Praktik semacam ini juga menimbulkan kerentanan bagi praktik-pratik pencucian uang, karena praktik-praktik semacam ini memungkinkan bagi nasabah untuk memperoleh dana halal (clean money) dari sumber pinjaman sebagai pengganti dana yang asal-usulnya dipertanyakan, yang ditempatkan di bank itu.

\section{PENUTUP \\ Kesimpulan}

Seluruh lembaga yang bergerak memberikan jasa di bidang keuangan atau terkait dengan keuangan, menjadi penentu atau garda terdepan dalam upaya pencegahan dan juga pemberantasan pencucian uang melalui peranan yang diberikan berupa melaporkan transaksi keuangan yang diwajibkan oleh undangundang. Perbankan sebagai lembaga yang mengelola keuangan terbesar dengan pangsa lebih dari 90\% dari seluruh lembaga keuangan yang ada; lembaga keuangan yang memberikan jasa keuangan yang memungkinkan untuk bertransaksi secara cepat dan tepat; serta adanya kerahasiaan bank yang cukup ketat, maka berpotensi menjadi sarana dan sasaran pencucian uang. Pencuci uang senantisa mencari tempat yang aman untuk menempatkan atau mencuci uangnya. 


\section{Rekomendasi}

Mengenai tantangan dan permasalahan operasional yang timbul belakangan ini, Bank Indonesia perlu mengambil langkah perbaikan, baik wajib dilakukan oleh bank maupun internal Bank Indonesia. Langkahlangkah perbaikan tersebut meliputi, yaitu:

Pertama, Penguatan pengendalian internal bank. Bank akan diminta untuk memperkuat seluruh lapis pengawasan untuk dapat mencegah, mendeteksi dan meminimalkan peluang dari risiko operasional.

Kedua, Penguatan aspek kebijakan Sumber Daya Manusia pada industri perbankan. Manajemen bank wajib untuk menjaga integritas pegawai antara lain melakukan penegakan prinsip know your employee. Tentu Bank Indonesia secara intensif harus melakukan evaluasi terhadap pelaksanaan kebijakan Sumber Daya Manusia yang dilakukan bank.

Ketiga, Penguatan pelaksanaan prinsip pengenalan nasabah. Bank Indonesia tentu meminta bank lebih aktif melakukan pemantauan transaksi pencucian uang dan pelaporan kepada PPATK. Bahkan, bank diminta melakukan kewenangan untuk penundaan transaksi jika mencurigakan.

Keempat, Bank sentral wajib untuk melakukan penyempurnaan fokus pengawasan dan pemeriksaan. Fokus pengawasan bank saat ini difokuskan kepada prinsip berbasis risiko, bank sentral akan meningkatkan fokus kepatuhan pada risiko yang melekat, terutama risiko operasional.

Kelima, Bank Indonesia seharusnya melakukan penyempurnaan terhadap ketentuan alat pembayaran menggunakan kartu (APMK) dengan mengeluarkan aturan baru yang mengatur aktivitas layanan nasabah prima, termasuk wealth management.

Keenam, Penguatan perlindungan atas nasabah. Dengan demikian, Bank Indonesia telah melakukan penataan organisasi, pelaksanaan fungsi pengaturan dan pengawasan yang akan menekankan kepada aspek perlindungan nasabah.

Ketujuh, Pemahaman nasabah akan pengetahuan dan informasi yang memadai serta pemahaman fungsi dan manfaat atas resiko produk dan jasa bank.

\section{DAFTAR PUSTAKA}

Buku:

Fuady, Munir, 2004, Hukum Perbankan Modern (Buku Kedua), Bandung: Citra Aditya Bakti.

Husein, Yunus, 2007, Bunga Anti Pencucian Uang, Bandung: Books Terrace \& Library.

Irman S. Tb., 2006, Hukum Pembuktian Pencucian Uang, Bandung: Mos Pub. \& AYYCCS Group.

Siahaan, NHT, 2005, Pencucian Uang dan Kejahatan Perbankan, Jakarta: Pustaka Sinar Harapan.

Sutedi, Adrian, 2007, Hukum Perbankan (Suatu Tinjauan Pencucian Uang, Merger, Likuidasi, dan Kepailitan), Jakarta: Sinar Grafika.

Sjahdeni, S. Remy, 2004, Seluk-Beluk Tindak Pidana Pencucian Uang dan Pembiayaan Terorisme, Jakarta: Grafiti.

\section{Peraturan Perundang-undangan:}

Undang-Undang No. 15 Tahun 2002 tentang Tindak Pidana Pencucian Uang (LNRI Tahun 2002 No. 30; Tambahan Lembaran Negara Republik Indonesia No. 4191).

Undang-Undang No. 25 Tahun 2003 tentang Perubahan atas Undang-Undang No. 15 Tahun 2002 tentang Tindak Pidana Pencucian Uang (LNRI Tahun 2003 No. 108; Tambahan Lembaran Negara Republik Indonesia No. 4324).

Undang-Undang No. 8 Tahun 2010 tentang Pencegahan dan Pemberantasan Tindak Pidana Pencucian Uang (LNRI Tahun 2010 No. 122; Tambahan Lembaran Negara Republik Indonesia No. 5164).

\section{Jurnal/Website:}

Zulkarnain Sitompul, "Tindak Pidana Perbankan Dan Pencucian Uang (Money Laundering)", Reformasi Hukum Vol. VII No. 2 Juli-Desember 2004. http://www.bis.org/bcbs diakses tanggal 25 Juni 2012. 